\title{
A contribuição de Pierre Bourdieu para a sociologia da arte (França e Brasil)
}

\author{
Alain Quemin ${ }^{1}$ (1) \\ Ana Paula Cavalcanti Simioni ${ }^{\mathrm{II}}$ (D)
}

\section{Introdução}

Que influência exerceu Pierre Bourdieu sobre a sociologia da arte? Em que consiste sua herança nesse domínio de investigação? Para tentar responder a tais questóes, parece-nos importante precisar nossa relação com esse objeto, seja pela nossa relação pessoal com Bourdieu, seja com o campo específico em questáo. Isso nos parece relevante na medida em que os julgamentos emitidos sobre Bourdieu e sua obra são, ainda hoje, afetados pela relaçáo de proximidade que muitos dos autores que o seguem tiveram com ele no passado, fosse como mestre, fosse como orientador, ou ainda por meio do contato possibilitado pelas instituições em que trabalharam.

$\mathrm{Na}$ segunda parte do texto, pretendemos esclarecer a importância de Bourdieu para a sociologia da arte francesa e também para a brasileira. Para tanto, foi preciso analisar a tomada de posiçấo de Pierre Bourdieu em relação à sociologia da arte preexistente, desde os seus primórdios, em fins do século XIX, até o início dos anos 1960. Assim, procuramos atentar-nos para o lugar de Bourdieu na refundação da disciplina Sociologia da Arte entre os anos 1960 e meados dos 1990, assim como para a dimensão internacional de seus efeitos. Nesse sentido, desejamos apontar que o Brasil possui papel relevante para a internacionalização e, portanto, disseminação do pensamento de Pierre Bourdieu, haja vista ser um dos países em que a recepção do autor é mais preeminente e onde ele desfruta um lugar ímpar como a grande referência na sociologia da arte.

\section{Pierre Bourdieu, um objeto de estudo passional: a posiçáo dos pesquisadores e suas relaçóes diante do objeto}

É preciso ter conhecido Pierre Bourdieu para falar dele com propriedade? No caso desse grande sociólogo, isso nos parece questionável. Um dos autores do presente artigo, Alain Quemin, pertence a uma geração de sociólogos que se doutorou na primeira metade dos anos 1990, período em que a atuação de Pierre Bourdieu sobre a sociologia francesa era evidente e determinante. Sua importância deixava-se perceber em diversos espaços, como nas classes preparató-

\footnotetext{
I'Institut d'Études Européennes, Université Paris 8 - Saint-Denis, França. E-mail: aquemin@univ-paris8.fr IIInstituto de Estudos Brasileiros, Universidade de São Paulo - São Paulo (SP), Brasil. E-mail:anapcs@usp.br Recebido em: 11/03/2019. Aprovado em: 13/05/2019.
} 
rias para os exames de ingresso nas Grandes Écoles, nos cursos de ciências sociais que eram oferecidos por várias universidades $\mathrm{e}$ também em algumas das prestigiosas Écoles Normales Supérieures (ENS). Nesse ponto, vale notar que, como Alain Quemin estudou na ENS de Cachan, foi menos exposto à sensibilidade bourdiesiana, o que seria muito diferente caso ele tivesse seguido a ENS da Rue d'Ulm. Bourdieu era também leitura obrigatória em diversos departamentos de universidades, especialmente em Amiens, Nantes ou Lyon, mas na Universidade de Paris X, Nanterre - onde Quemin se formou —, a influência de Bourdieu era bem menos sensível, assim como no l'Institut d'Études Politiques de Paris, instituição em que realizou seu Diplôme d'Études Approfondies (DEA). Já na École des Hautes Études en Sciences Sociales (EHESS), onde fez seu doutorado em Sociologia, tal importância era preemente.

Convém sublinhar que, nessa época, na França, a influência de Pierre Bourdieu era então dupla. Possuía a forma de um interesse - ou melhor, um verdadeiro fascínio entre aqueles que eram adeptos (ou talvez pudéssemos dizer seguidores) do pensamento do mestre; ou, inversamente, se manifestava por uma verdadeira rejeição ${ }^{1}$. Essa segunda postura levou alguns autores a ensaiarem a construção de análises e até mesmo de modelos alternativos cujo principal objetivo era enfraquecer o esquema analítico daquele que eles tanto admiraram ou idolatraram anteriormente. Comparado a qualquer outro autor, esse posicionamento com respeito a Pierre Bourdieu tinha então um componente emocional táo forte que nos pareceu indispensável especificar aqui, desde o início dessa contribuição, a situação do primeiro dos dois autores deste texto, como uma forma de socioanálise (Bourdieu, 1991; 2004).

Mesmo tendo ingressado no doutorado na EHESS, onde Bourdieu era professor e orientador, Quemin teve um acesso particularmente limitado aos cursos por ele promovidos, uma vez que estes não eram reuniōes verdadeiramente abertas. Pôde assistir a ele em suas conferências no Collège de France, onde aquele grande professor, brilhante e carismático, atraía tantos interessados que era capaz de congregar uma massa de ouvintes. Quemin quase o teria encontrado em outra ocasião, durante a defesa de tese de Gisèle Sapiro, que havia sido orientanda do mestre e de quem já era muito amigo, caso a defesa de ambos não tivesse ocorrido no mesmo dia e hora, embora em diferentes edifícios da EHSS; a dela no 54 Boulevard Raspail, e a dele no número 105 da mesma rua.

No entanto, Alain Quemin possuía interesse efetivo no trabalho de Pierre Bourdieu, autor que ele lia desde a graduação em Ciências Sociais. Desapontado com o nível de discussóes levado a cabo no Instituto de Estudos Políticos de Paris, em que grande parte dos professores era proveniente de empresas privadas ou da área de administração, esperava acessar uma discussão mais aprofundada na EHESS, de maneira especial na área de sociologia da arte (especificamente em sociologia das artes visuais), pela qual se sentia bastante atraído.

O manual do aluno disponibilizado na matrícula na EHESS apontava três opçōes de professores na área pretendida: Pierre Bourdieu, Raymonde Moulin e Jacques Leenhardt. A primeira opção estava já de antemão descartada, pois, não tendo completado

1 Entre os que defendiam tal posição, citam-se, por exemplo, Luc Boltanski ou mesmo Pierre-Michel Menger. 
com ele o seu mestrado (o equivalente ao master 1), ou com um de seus colaboradores imediatos (nesse caso, seria melhor dizer, discípulos), era impossível ser acolhido pelo mestre. Ou seja, a única opção era realizar um novo DEA, pois era impossível iniciar a orientação com Bourdieu diretamente no doutorado. A escolha recaiu então sobre Raymonde Moulin, de quem ele havia lido alguns trabalhos, especialmente o artigo "Les bourgeois amis des arts” (MOULIN, 1976), que lhe parecera muito interessante. Seu primeiro encontro com ela foi crucial.

Desde então, Raymonde Moulin fora muito benevolente, em parte também porque alimentava um complexo de inferioridade, que ela admitiu aliás prontamente, em relação aos seus colegas sociólogos provenientes da filosofia, como Pierre Bourdieu e Jean-Claude Passeron, enquanto ela mesmo teria vindo apenas da história. Esse sentimento foi aprofundado pela grande demora em ser finalmente escolhida como orientadora, o que só ocorreu quando Pierre-Michel Menger ${ }^{2}$, que desertara da orientação de Pierre Bourdieu, a procurou para concluir sua tese. Entre os três nomes - Bourdieu, Moulin e Leenhardt —, Pierre Bourdieu era quem desfrutava maior prestígio intelectual, mas também representava uma trincheira, em parte graças à perspectiva hegemônica de sua abordagem. Raymonde Moulin também ocupava uma posição institucional forte, por conta da sua capacidade de formar alianças com outros sociólogos, como Claudine Herzlich, bem como com historiadores, particularmente com Jacques Revel, de quem era muito próxima, o que lhe permitia o acesso a toda uma rede de intelectuais e perspectivas disciplinares ampliadas. Tendo se formado em História, antes de realizar um doutorado em Sociologia sob a orientaçáo de Raymond Aron, Raymonde Moulin era muito bem-vista pelos historiadores. Ela também jamais escondeu o fato de que ser mulher, numa época em que o mundo acadêmico possuía tão poucas delas, fazia com que se beneficiasse de uma posição ultraminoritária nesse meio. Enquanto isso, Jacques Leenhardt ${ }^{3}$ ocupava uma posição mais marginal na instituição naquele momento e consagrava-se mais à sociologia da literatura.

Em busca de uma formação de qualidade em sociologia melhor do que havia recebido até então, Quemin decidiu inscrever-se em muitos cursos, muito mais do que o necessário para os alunos regulares de primeiro ano. Naturalmente, dada a importância de Bourdieu, desejava seguir seu seminário, mas, ao indagar na secretaria sobre

2 Pierre-Michel Menger (1953) formou-se em filosofia na ENS e posteriormente iniciou seu doutorado na EHESS, sob a orientação de Pierre Bourdieu, mas, por divergências com o mestre, optou por transferir-se para Raymonde Moulin, com quem o concluiu. Ingressou como pesquisador no Centre National de la Recherche Scientifique (CNRS) em 1978 e tornou-se professor na EHESS em 1987. Desde 2013, é professor no Collège de France. Entre suas publicaçôes, destacamos: Profession artiste. Extension du domaine de la création (Textuel, 2005); Le travail créateur. S'accomplir dans l'incertain (Le Seuil, 2009); entre diversos outros livros e artigos.

3 Jacques Leenhardt é professor da EHESS, onde participa do Centre de Recherches sur les Arts et le Langage (CRAL), orientando diversas teses em sociologia da arte (também sobre América Latina e Brasil). Formou-se em Filosofia e Sociologia (área na qual concluiu seu doutorado, em 1972). Inicialmente trabalhava mais com sociologia da literatura, o que se vê por seu primeiro livro, Lecture politique du roman. La Jalousie d'Alain Robbe-Grillet (Éd. de Minuit, 1973). Entre suas muitas publicaçóes, destacamos: Lire la lecture. Essai de sociologie de la lecture (com Pierre Józsa e Martine Burgos) (Le Sycomore, 1982); Dans les jardins de Roberto Burle Marx (Actes, 1994), sob sua organização. 
a inscrição, foi-lhe dito que esse seminário era reservado a seus estudantes de doutorado e seus parceiros! Para compensar, Quemin decidiu então matricular-se em cursos ministrados por duas colaboradoras próximas a Pierre Bourdieu, Monique de Saint-Martin e Francine Muel-Dreyfus, e foi por meio delas que obteve uma socializaçáo mais profunda com o pensamento do autor. Assim, num ambiente mais informal pôde seguir a distância, por força das circunstâncias, o seminário de Pierre Bourdieu, em virtude da relação de amizade com Gisèle Sapiro. Ela sempre contava com humor e inteligência as novidades das últimas sessóes do seminário para o pequeno grupo de amigos a que ambos pertenciam. Paradoxalmente e apesar de nunca ter estado em contato direto com Pierre Bourdieu, Alain Quemin teve acesso ao autor por meio desses vários canais, estando assim imerso em um ambiente marcado pelo pensamento, bem como pelo carisma, de Bourdieu, mas sem ter acesso direto à sua pessoa. Isso lhe permitiu escapar da dimensão emocional que marcava a sua relação com os seus discípulos e pares imediatos, a qual, ainda hoje, deixa marcas.

Alain Quemin acredita que a relação teria se desgastado com Raymonde Moulin, e mais ainda com Pierre-Michel Menger, se tivesse efetivamente seguido os seminários de Pierre Bourdieu, na medida em que a EHESS era profundamente atravessada por clivagens entre os professores, o que se espraiava pelos seus orientandos. Os territórios dos quais eram incentivados a participar dependiam das sensibilidades e das alianças travadas entre os orientadores. Raymonde Moulin sempre nutriu uma relação complexa com Bourdieu, uma mistura de fascinação e estima por seu trabalho (pelo menos por aquela parte da produção por ela considera- da menos dogmática) e por suas realizaçôes, mas também possuía lucidez sobre as dificuldades que advinham de sua personalidade. Além disso, ela era uma colaboradora próxima de Raymond Aron e, ao mesmo tempo, se relacionava com Bourdieu tomando por base certa distância etária - ela nasceu em 1924 e ele alguns anos depois, em 1930. Assim, Alain Quemin pôde também aprender muito sobre Bourdieu com Moulin, cujo olhar a respeito desse grande intelectual desempenhou importante filtro.

Já Pierre-Michel Menger ficou muito marcado por uma rápida passagem como aluno de Pierre Bourdieu, da qual parecia guardar alguma amargura. Ele considerava que Alain Quemin era excessivamente interessado pela perspectiva do colega e, por isso, criticava Quemin por ser determinista, o que para o entáo doutorando parecia bastante normal, embora náo se tratasse de um determinismo de tipo mecanicista. Hoje isso pode parecer surpreendente, mas na época a influência de Pierre Bourdieu era tamanha na sociologia francesa que, para lograr se destacar enquanto sociólogo, por vezes era preciso colocar em questão as próprias bases da disciplina, pois estas pareciam estar fortemente associadas ao autor. Anos mais tarde, Pierre-Michel Menger tornar-se-ia professor no Collège de France, porquanto não havia nenhum professor na área de sociologia desde a morte de Pierre Bourdieu. Praticando uma sociologia mais setorial e inspirada por uma perspectiva econômica, Menger foi eleito a uma cadeira não intitulada propriamente de Sociologia, como era a de Bourdieu, contudo de Sociologia do trabalho criativo. Com isso, afastava-se também do domínio mais estreito da sociologia da arte, ao qual havia se dedicado quando fizera seu doutorado, sob a orientação de Raymonde Moulin. 
Deve-se notar, porém, que a sociologia da arte esteve presente na trajetória de ambos os autores e, embora não tenha sido nesse domínio específico que tenham ingressado no Collège de France, consistiu em um passo significativo para o reconhecimento posteriormente conquistado.

Pareceu-nos importante desenvolver a posição de Alain Quemin em relação a Pierre Bourdieu durante seus anos de formação, náo pelo prazer da anedota, mas para especificar seu lugar, que é tanto de um observador quanto o de um autor que tem investido nesse domínio nos últimos decênios. $\mathrm{O}$ mesmo exercício de socioanálise é relevante para a segunda autora do texto, que se desenvolveu em um ambiente geográfico distante de Bourdieu — o Brasil —, no entanto muito impactado por seu pensamento.

Ana Paula Cavalcanti Simioni teve contato com as teorias de Pierre Bourdieu ainda em seus tempos de escola, por meio de seu padrasto, Fernando Lefèvre, semiólogo formado na França e professor da Universidade de São Paulo (USP) e que havia lhe apresentado alguns textos publicados em Economia das trocas simbólicas. Esse interesse aprofundou-se quando, em 1990, ela ingressou no curso de Ciências Sociais da USP, instituição fortemente marcada pela sociologia francesa desde sua fundação, na década de
$1930^{4}$. Já no primeiro ano, teve aulas com Sergio Miceli, sociológo reconhecido e muito atuante no desenvolvimento da sociologia da cultura no país, que havia organizado o já citado livro, o primeiro traduzido para o português (Bourdieu, 1974) ${ }^{5}$. Como assinalam Gisèle Sapiro e Bustamante (2009), Miceli pode ser considerado como um dos mais importantes mediadores para o processo de internacionalização inicial da obra de Bourdieu, de quem havia sido orientando de doutorado na EHESS, entre 1974 e 1978. Em 1991, Ana Paula tornou-se estagiária do Projeto História Social das Artes Plásticas no Brasil, desenvolvido no Instituto de Estudos Econômicos, Sociais e Políticos de São Paulo (IDESP), sob coordenação do mesmo professor, experiência que foi decisiva para que, já nos anos iniciais de sua formação, escolhesse o subcampo da sociologia da arte como área de atuação ${ }^{6}$.

Ao longo dos anos 1990, a sociologia da arte era uma área embrionária, restrita a algumas poucas universidades brasileiras (USP, Universidade Estadual de Campinas - UNICAMP, Pontifícia Universidade Católica de São Paulo — PUC-SP e Universidade Federal do Rio de Janeiro UFRJ, principalmente), e cujo reconhecimento derivava em grande parte da atuação direta de intelectuais que dela tratavam, tais

4 Sobre as relaçôes entre a França e a Faculdade de Filosofia da USP, ler, entre outros: Miceli, 1989; Jackson, 2007; Peixoto, 2000; Pulici, 2004.

5 Sobre a importância de Sergio Miceli como introdutor de Bourdieu no Brasil e, particularmente, no campo da sociologia da cultura, ler: Bortoluci, Jackson e Pinheiro Filho, 2015.

6 A autora manteve-se ao longo do mestrado e do doutorado na Sociologia da USP sob orientação de Sergio Miceli. Entre 1996 e 1999, realizou mestrado sobre Di Cavalcanti baseada em premissas acentuadamente bourdiológicas, centradas em noçôes como campo e habitus. Em seu doutorado, abordou a produção das mulheres artistas acadêmicas brasileiras utilizando noçôes de Bourdieu, mas abrindo-se para estudos de gênero e discussōes da história da arte feminista (incorporando autoras como Linda Nochlin, Griselda Pollock, entre outras), pouco contempladas por Bourdieu. A despeito de A dominação masculina, ver: Simioni, 2008. 
como o próprio Sergio Miceli, e também Renato Ortiz, Glaucia Villas Bôas, entre alguns outros. No mais importante congresso da área, da Associação Nacional de Pós-Graduação e Pesquisa em Ciências Sociais (ANPOCS), as discussóes sobre arte estavam então subordinadas a grupos de trabalho mais sedimentados, como Pensamento Social Brasileiro, ou Museus e Patrimônio. Apenas mais recentemente, em 2013, lograram autonomizar-se em torno de um simpósio temático intitulado $\mathrm{O}$ Mundo das Artes: Culturas Artísticas, Práticas Sociais e Dimensóes Simbólicas, sob a coordenação de Glaucia Villas Bôas (UFRJ) e Edson Farias (Universidade de Brasília — UnB). Essa iniciativa continuou nos dois anos seguintes, por meio do grupo de trabalho coordenado por Edson Farias e Ana Paula Simioni intitulado Arte e Cultura nas Sociedades Contemporâneas, tornado fórum em 2017 sob a organização de Lígia Dabul (Universidade Federal Fluminense - UFF) e Gloria Diógenes (Universidade Federal do Ceará - UFC). Isso indica que a sociologia $\mathrm{da}$ arte conquistou certo reconhecimento tardiamente (e, vale notar, de modo instável) naquele que é o mais importante fórum das ciências sociais no Brasil.

Também foi só há pouco tempo, em 2007, que se formou um grupo de sociologia da arte nos congressos promovidos pela Sociedade Brasileira de Sociologia, sob a coordenação de Lígia Dabul, Maria Lucia Bueno (Universidade Federal de Juiz de Fora - UFJF) e Sabrina Parracho
Sant'Anna (Universidade Federal Rural do Rio de Janeiro - UFRRJ), o qual tem se mantido com regularidade e estabilidade ${ }^{7}$. Outros índices desse reconhecimento relativo da área podem ser notados por meio das classificaçôes das agências federais e estaduais. Por exemplo, no Conselho $\mathrm{Na}$ cional de Desenvolvimento Científico e Tecnológico (CNPq), na Coordenação de Aperfeiçoamento de Pessoal de Nível Superior (CAPES) e na Fundação de Amparo à Pesquisa do Estado de São Paulo (FAPESP) não existe na área de sociologia a rubrica sociologia da arte, o que obriga os pesquisadores ainda hoje a assinalarem outras sociologias específicas como campo de atuação, o que invisibiliza a particularidade de suas pesquisas e temáticas.

Tendo em vista esse breve cenário da área, entende-se que, ao escolher sociologia da arte em 1990 como um destino profissional, Ana Paula Simioni optou por abraçar um risco, posto que essa área gozava de menor reconhecimento que outras temáticas, tais quais trabalho e classes sociais; violência; raça e pensamento social brasileiro (área de prestígio acentuado no campo da sociologia da cultura no país). Era ainda uma escolha possível em poucas instituiçôes, como a USP, onde a influência de Bourdieu era (e ainda é) absolutamente central.

A relação com Bourdieu foi, desta feita, possibilitada e mediada pela atuação e pelas leituras promovidas por Sergio Miceli, de quem foi orientanda no mestrado e no doutorado. A atuação desse professor foi

7 A esse respeito, ler: Quemin e Villas-Bôas, 2016; Bueno, Sant'anna e Dabul, 2018; e ainda o dossiê “Sociologia da Arte Hoje”, organizado pelo professor João Gabriel Teixeira (2005), publicado na revista Estado e Sociedade, publicada pela Universidade de Brasília (UnB). 
fundamental para a formação de uma geraçáo de pesquisadores em sociologia da arte ${ }^{8}$ e da cultura e deve também ser notada no campo editorial. Além de ter organizado a primeira coletânea dedicada ao autor em solo brasileiro, no período em que dirigiu a Editora da USP (EDUSP), organizou a traduçáo de uma série de livros que impactaram o pensamento de Bourdieu, o que se tornou essencial para que compreendamos no Brasil o seu diálogo com outros autores ${ }^{9}$. Mais recentemente esteve também responsável pela indicação de títulos para tradução pela editora Companhia das Letras, os quais ampliaram consideravalmente o acesso do público brasileiro às obras não só do próprio Bourdieu, mas de seus interlocutores. O contato pessoal com Bourdieu, vislumbrado por Ana Paula Cavalcanti Simioni quando teve a oportunidade de realizar seu doutorado sandwich na França, entre 2002 e 2003, e a presença em seus seminários na EHESS, bem como as liçôes no Collège de France, tiveram de ser abortados em virtude da morte do pensador francês, em 2002. Assim, tal qual no caso de Alain Quemin, Simioni pode ser considerada uma socióloga da arte leitora de um Bourdieu que acessara não diretamente, mas por meio das mediaçóes, em seu caso levadas a cabo por um de seus mais reconhecidos discípulos.

\section{A tomada de posição de Pierre Bourdieu em relação à sociologia da arte preexistente: dos primórdios da sociologia da arte até o início da década de 1960}

Os primórdios da sociologia da arte remontam, na Europa e de maneira particular na França, praticamente ao surgimento da própria disciplina ${ }^{10}$. Embora uma comunidade de pesquisadores voltada para questóes, métodos e problemas comuns à área tenha se

8 Sergio Miceli formou dezenas de profissionais. Aqui mencionamos apenas alguns que se dedicam mais diretamente à sociologia da arte (incluindo artes visuais, literatura, música, fotografia, cinema e arquitetura), por data de defesa de seus doutorados: Maria de Lourdes Eleuterio (1997), Maria Beatriz Coelho (2000), Maria Tarcila Bega (2001), Fernando Antonio Pinheiro Filho (2001), Ana Paula Cavalcanti Simioni (2004), Fernandes (2005), Marco Aurélio Paiva (2005), Alexandre Bergamo Idargo (2006), Gilmar Santana (2007), Iara Rolim (2009), Dmitri C. Fernandes (2010), Marcio Nascimento (2010), Lilian Sampaio (2011), Flavio Rosa de Moura (2011), Aluizio de Oliveira (2012), Erica Magi (2016), Camila Gui Rossatti (2016). Mais informaçóes disponíveis em: <http:// lattes.cnpq.br/7114904634089152>. Acesso em: 10 abr. 2019. De modo geral, tais estudos compartilham um interesse por produçóes de artistas (em suas diversas linguagens) brasileiros, seguindo uma orientação sociológica de matriz predominantemente bourdiesiana, atenta, portanto, às particularidades da noção de campo no Brasil. Em alguns desses trabalhos, a dimensão da indústria cultural é também dimensão relevante, embora normalmente haja tendência de se ocupar mais de criadores ligados às esferas da produção erudita.

9 Sergio Miceli presidiu a EDUSP entre 1994 e 1999. Nessa ocasião, promoveu a tradução de títulos fundamentais para a área de sociologia da cultura, entre eles: Fundamentos racionais e sociológicos da música, de Max Weber, publicado em 1995 (vale notar que em seus cursos Miceli abordava o quanto Bourdieu lera as teorias weberianas e as havia incorporado em sua teoria da autonomização dos campos); O declínio dos mandarins alemães, de Fritz Ringer (publicado em 2001, mas indicado durante a gestấo de Miceli); Mecenas e pintores: arte e sociedade na Itália barroca, de Francis Haskell (publicado em 1997); entre outros. Na Companhia das Letras, Miceli atuou como consultor para a série de livros publicados sobre história social da arte, entre eles vários que eram lidos em seus cursos na USP no original, como Academias de arte, de Nikolaus Pevsner; e A pintura da vida moderna: Paris na época de Manet e seus seguidores, de T. J. Clark. Mais informaçóes disponíveis em: <https://www.companhiadasletras.com. br/detalhe.php?codigo=12073>. Acesso em: 5 fev. 2019.

10 Para uma história breve do desenvolvimento da sociologia da arte, consultar: Quemin, 2017. 
formado mais tardiamente, os temas de arte e cultura aparecem desde cedo nos escritos de sociólogos. O primeiro livro a combinar arte e sociologia foi assinado por um autor francês, hoje absolutamente esquecido, Jean-Marie Guyau (1854-1888). Em L'art au point de vue sociologique, publicado em 1889, ele tentou explicar as obras de arte com base em suas próprias condições materiais de produção, por uma perspectiva mais filosófica do que propriamente sociológica. Já no campo da sociologia propriamente, o fundador da disciplina na França, Émile Durkheim, embora não tenha escrito muito sobre arte, reservou uma coluna para "sociologia estética" na revista que criou e editou, L'Année sociologique, a qual contou com a contribuição particular de seu sobrinho, o célebre antropólogo Marcel Mauss. Durkheim teve influência sobre o esteta Charles Lalo (1877-1953), a quem devemos L'art et la vie sociale, publicado em 1927.

Com respeito à produçáo náo francesa no período de ascensão da sociologia, o século XIX, deve-se notar que, mesmo que Karl Marx não tenha escrito muito sobre arte, suas ideias alimentaram uma corrente de pensamento que mais tarde tomaria esse objeto como central, como é o caso da Escola de Frankfurt, associada a nomes como Theodor W. Adorno e Herbert Marcuse, e que também impactou visivelmente as obras de Georg Lukács e seu discípulo Lucien Goldmann. Nos primórdios do século XX e ainda entre os pioneiros da disciplina, Max Weber escreveu uma sociologia da música (publicada originalmente em 1921), Sociologie de la musique, enquanto Georg Simmel abordou a produção estética em muitos de seus escritos ${ }^{11}$, no entanto vários desses textos dedicados à arte, durante a primeira metade do século XX, assinalam certo grau de indeterminaçấo disciplinar. Podem ser de fato designados como sociologia, ou se aproximam mais da estética, história ou filosofia da arte?

Outro caso que parece particularmente revelador é o de Pierre Francastel (19001970). Ele foi um historiador da arte incontestável, mas seu status de sociólogo da arte parece mais discutível, não sendo consensualmente aceito. Embora, e isso é importante sublinhar, tenha sido ele a criar a expressão "sociologia da arte" e o primeiro a ocupar uma cadeira nesse domínio (mais precisamente a cátedra de "sociologia das artes plásticas", criada em 1948 dentro da sexta seção da École Pratique des Hautes Études) (Quemin \& Lévy, 2010), a contribuição de Francastel na sociologia é relevante na medida em que, ao adotar tal título para sua cátedra, tenha afirmado que a arte poderia se tornar objeto de uma análise sociológica, o que na época não era evidente e constituiu mesmo para muitos uma heresia. A arte era então, antes de tudo, um objeto da estética, da história da arte e, vale notar, de uma história da arte exclusivamente internalista.

A "sociologia da arte" praticada por Francastel náo parece hoje convincente, mas ela abriu as portas, tanto institucionais quanto simbólicas, para a associação entre arte e sociologia, fixando mesmo essa uniâo em um espaço institucionalmente privilegiado, como era o da École Pratique des Hautes Études. Se é sabido que Pierre Bourdieu leu extensivamente os grandes fundadores da sociologia, tais quais Marx, Durkheim e We-

11 Por exemplo, Brücke und Tür. Essays des Philosophen zur Geschichte, Religion, Kunst und Gesellschaft (K. F. Koehler Verlag, 1957). Sobre o autor, ler também: Waizbort, 2000; Villas Bôas e Oelze, 2016. 
ber, de cuja própria teoria assinalou diversos empréstimos, tal como o fez com Simmel e Veblen, ele leu Pierre Francastel, em quem encontrou um autêntico e absoluto oposto.

\section{Bourdieu e a refundação da sociologia da arte (1960-1980):}

Apesar da emergência de algumas reflexôes sobre arte já nos primórdios da sociologia, foi preciso esperar ao menos até a década de 1960 para que a sociologia da arte, tal como a compreendemos hoje, tomasse forma. Isso ocorreu na França. Os trabalhos pioneiros de pesquisa realizados por Pierre Bourdieu e Alain Darbel sobre os públicos da arte, que resultaram em L'amour de l'art: les musées et leur public, publicado em 1966, assim como a publicação do doutorado de Raymonde Moulin no livro intitulado Le marché de la peinture en France, em 1967, constituíram a base sobre a qual se erigiu a sociologia da arte contemporânea, que é hoje muito mais ampla do que esses nomes e publicaçôes.

Antes mesmo de publicar L'amour de l'art, Bourdieu havia trabalhado, com auxílio de diversos colaboradores, em outro tema correlato ao da arte: Un art moyen. Essai sur les usages sociaux de la photographie, editado em 1965. Nele, Bourdieu e outros pesquisadores dedicaram-se, como indica o título, à fotografia, numa época em que esse meio era menos institucionalizado e reconhecido do que é hoje, porém a obra exerceu menos impacto entre os sociólogos interessados no campo artístico do que L'amour de l'art, que atacou o coração do mundo da arte - a cidadela dos museus.

Naquela época, a sociologia da arte ocupava um lugar muito restrito no panorama da sociologia francesa. Esta esta- va dominada por áreas como a sociologia do trabalho, que adquirira proeminência no pós-guerra, uma vez que havia uma urgência social derivada da necessidade de reconstrução dos países afetados. Concedia-se também um lugar de honra para o tema da educaçáo, diante das tensóes decorrentes da expansáo do sistema educacional ao longo desses anos. Assim, ainda que no período tenha havido produção relevante sobre sociologia da arte, era algo que permanecia menos visível do que outros temas. Isso explica o fato de Pierre Bourdieu, apesar de sua contribuição significativa para a sociologia da arte, ter se dedicado mais à sociologia da educação e da cultura, que eram áreas que gozavam de mais legitimidade e prestígio e que pareciam mais promissoras. Ou seja, muito embora a contribuição de Bourdieu (e Darbel) com L'amour de l'art seja incontestável, especialmente porque ainda hoje as pesquisas levadas a cabo sobre públicos são reconhecidas como atuais e inovadoras, isso foi pouco notado na época, dada a natureza marginal da sociologia da arte no interior da disciplina como um todo.

É importante lembrar em que contexto Pierre Bourdieu desenvolveu seu trabalho sobre museus e seus públicos. Hoje, as conclusóes podem parecer óbvias, uma vez que quase deram origem a uma espécie de lei social que tem sido constantemente verificada desde então: a frequência aos museus parece estar altamente correlacionada com o nível de formação escolar. Essa conclusão atualmente não parece mais táo chocante, mas na época caiu como uma bomba. L'amour de l'art foi escrito contra Pierre Francastel, em uma menção já no começo do livro a ridicularizá-lo, zombando de sua ingenuidade ${ }^{12}$.

12 Com efeito, em $O$ amor pela arte, Francastel é o primeiro autor interpelado. Ver: Bourdieu e Darbel, 2003. 
De fato, o livro inteiro foi escrito contra ele. Quando Quemin compartilhou essa hipótese com Raymonde Moulin, ela contou a seguinte anedota: certo dia, quando surgiu um resultado que mostrava todo o peso da influência social - especialmente da educação — sobre a apreciação cultural, Bourdieu exultante exclamou: "Ah, isso é excelente! Vai fazer Francastel espernear!".

L'amour de l'art não teve impacto tão considerável quanto Les héritiers (Bourdieu e Passeron, 1964) ou La reproduction (Bourdieu e Passeron, 1970) na sociedade francesa de meados dos anos 1960/70, mas exerceu influência decisiva no mundo da arte desse período. Em uma entrevista realizada em 2007 , por ocasião do $30^{\circ}$ aniversário do Centro Georges Pompidou, Jean-Hubert Martin, que na época da criação dessa instituição, em 1977, era um jovem curador ${ }^{13}$ no Museu Nacional de Arte Moderna (MNAM), afirma: "Fomos consultados, nós, jovens curadores, para saber que personalidades gostaríamos de ouvir. E foi incrível, todos nós expressamos o mesmo desejo: todos nós queríamos conhecer Bourdieu. Seus trabalhos tiveram uma enorme influência sobre nós" (apud Quemin, 2007, p. 494-498).

O impacto extremo da obra de Pierre Bourdieu no setor cultural também pode ser medido por intermédio de outro exemplo, também emprestado do Centro Pompidou: um projeto cultural central dos anos 1970 . Por muito tempo, as pesquisas de opiniáo pública realizadas no Centro Pompidou obedeceram a uma classificação de origens sociais essencialmente binária. As autorida- des públicas francesas usavam desde 1954 a nomenclatura de grupos socioprofissionais estabelecidos pelo Institut National de la Statistique et des Études Économiques (INSEE), instituição que vinha refletindo sobre o sistema de representaçôes de estratificação social, o que se modificou em 1982, com a nomenclatura PCS (profissóes e categorias socioprofissionais $)^{14}$. Em ambos os casos, trata-se de nomenclaturas bastante complexas, e a primeira, que então prevaleceu, foi organizada em nove categorias, que não seguiam uma ordem hierárquica. Assim, o primeiro grupo reunia operadores agrícolas, o segundo os agricultores assalariados (um dos conjuntos de menor status social na sociedade francesa da época) e o terceiro os chefes da indústria e comércio (tanto industriais quanto pequenos comerciantes). Essa nomenclatura foi então criticada, o que levou à sua revisão e a seu completo abandono em 1982, quando se passou a utilizar uma nova classificação, que seguia as hierarquias sociais. A verdade é que se tratava de uma nomenclatura oficial e, portanto, amplamente utilizada em investigaçôes do governo.

Muito embora o Centro Pompidou fosse uma organização pública, havia decidido recusar a classificação pública oficial usada para mensurar a estratificação social. Por quê? Porque todo o projeto de Beaubourg foi banhado por uma ideologia muito marcada pelo pensamento de Pierre Bourdieu. Aqueles que realizaram os primeiros levantamentos do público frequentador do Beaubourg eram então estudantes e/ou discípulos de Pierre Bourdieu, tais

13 No Brasil, os conservadores de museus são denominados de curadores.

14 Sobre as nomenclaturas na França, ler: Desrosieres e Thevenot, 1988. 
como Nathalie Heinich, Jean-Louis Fabiani $^{15}$ e Pierre-Michel Menger, hoje três nomes centrais na sociologia da arte francesa. Naquele momento náo ocorrera aos encarregados da direçáo do Pompidou se dirigir a ninguém fora da órbita de Pierre Bourdieu e seus colaboradores para pensar em realizar investigaçóes. Convém notar, e talvez isso intrigue retrospectivamente os curadores do presente, que todos os temas eram eminentemente ligados às preocupaçóes despertadas pela sensibilidade sociológica de Bourdieu (as coleçóes, por exemplo, não eram estudadas!). A temática dos públicos era absolutamente central nas pesquisas e orientava-se de maneira especial para a compreensáo do peso que o meio social e o grau de instrução tinham em sua conformaçáo, respondendo, como se vê, a uma perspectiva bastante marcada pela visão do autor.

A influência da sociologia da arte de Bourdieu sobre a prática não se limitou ao caso emblemático do Beaubourg. Ela foi também importante no Departamento de Estudos e Pesquisas do Ministério da Cultura, criado em 1963, mais tarde chamado de Departamento de Estudos e Prospectiva, que contava com o apoio ativo de Augustin Girard, importante agente daquela instituição cultural. Nesse caso, novamente, o impacto do autor levou a uma multiplicação de investigaçóes voltadas ao estudo dos públicos, como se essa temática monopolizasse os interesses em arte e cultura do ponto de vista sociológico.

Se o sucesso de Pierre Bourdieu era indiscutível no mundo da arte, desde o fim da década de 1960 e durante toda a década de 1970, já no campo acadêmico ele parecia mais interessado em náo ficar restrito a uma área que, naquele momento, poderia parecer limitada demais diante da sociologia que se praticava. É improvável que um grande texto de Pierre Bourdieu (escrito com Yvette Delsaut), O costureiro e sua grife, que ele escolhera como sua primeira contribuição para o lançamento de sua própria revista, a Actes de la Recherche en Sciences Sociales, em 1975 - o que evidencia a importância que ele próprio atribuía a esse artigo —, fosse percebido como um artigo de sociologia da arte, mesmo abordando um tema correlato, como a alta-costura. Os autores classificariam o texto como pertencente à sociologia da cultura, que na época parecia diversa da sociologia da arte, e dotada de mais centralidade no interior do campo sociológico.

Provavelmente o mesmo poderia ser dito sobre $A$ distinção (Bourdieu, 1979), uma obra fundamental para o que se pode designar sociologia da cultura, apesar de conter um grande número de reflexóes e dados que podem ser claramente relacionados à sociologia da arte. Será que Pierre Bourdieu já tinha em vista pleitear o ingresso no Collège de France e percebeu que a sociologia da arte era um setor visto como muito pontual, especializado demais do ponto de vista dessa instituição? Ao longo do tempo, a estratégia de Pierre Bourdieu consistiu em apresentar-se mediante um perfil o mais generalista possível. Em primeiro lugar, vinha a área da educaçáo, levando-se em conta o seu trabalho bastante especializado, na Argélia, que estava fortemente ligado à sua experiência pessoal, o

15 Jean-Louis Fabiani defendeu seu doutorado em 1980, sob a orientação de Pierre Bourdieu. A tese intitula-se La crise du champ philosophique, 1880-1914: contribution à l'histoire sociale du système d'enseignement. É professor da EHESS, vinculado ao Centre Raymond Aron, desenvolvendo pesquisas na área de sociologia dos intelectuais e da recepção. 
qual, quando foi publicado, ecoava profundamente as preocupaçóes de seu tempo. Depois primordialmente a cultura, uma noção tão abrangente, por seus diversos significados, que poderia ser vista como vinculada aos próprios fundamentos da sociologia. Foi assim que Pierre Bourdieu criou um laboratório o Centre de Sociologie de l'Éducation et de la Culture - que, como o próprio nome indica, respondia ao problema da educaçáo como um tema central de sua época, tão marcado pelos eventos de maio de 1968, mas que se propunha também a analisar a importância da vasta área da cultura para a compreensão dos fenômenos sociais. Essa foi uma estratégia inteligente e bem-sucedida.

Pierre Bourdieu foi, assim, eleito para o Collège de France adotando o título o mais abrangente possível para a cátedra que propunha, o de Sociologia, contra Alain Touraine, que de sua parte havia efetuado uma escolha mais restrita, a de Sociologia do Trabalho. Nos últimos anos de vida, porém, Bourdieu abraçou uma grande variedade de temas e objetos. Como ele tinha em vista uma abertura sempre o mais larga possível para seus objetos, não poderia ser apenas um sociólogo da arte nem, ao fim e ao cabo, de fato um sociólogo da arte. Enquanto isso uma colega e concorrente como Raymonde Moulin, em parte por estar estritamente associada a esse domíno específico de pesquisa, acabou desempenhando papel central na afirmação dessa área no interior da sociologia francesa.
A influência que Raymonde Moulin exerceu no nível institucional na França constitui um caso homólogo ao de Claudine Herzlich $^{16}$, outra personagem da ENESS que teve papel fundamental para o reconhecimento da área da sociologia da doença e da medicina. Enquanto ela introduziu autores americanos, como Eliot Freidson, Moulin inspirou-os.

Bourdieu havia aberto o terreno para os estudos sociológicos da arte, mas náo o definira como um campo específico, dedicando-se mais à educação e à cultura, que eram mais centrais para a sociedade francesa dos anos 1960. Entre as principais realizaçóes de Raymonde Moulin, além da publicação de seu livro em 1967 - Le marché de la peinture en France -, que é reconhecidamente um dos mais importantes para a sociologia $\mathrm{da}$ arte ainda hoje, por dotar a área de visibilidade e atribuir à produção artística papel institucional essencial, deve-se ainda levar em conta sua atuação institucional. Ela foi por muitos anos membro do Comitê Nacional do Centre National de la Recherche Scientifique (CNRS), oferecendo um rosto ao domínio que ela representava no seio da disciplina, enquanto reunia também em torno de si um grupo inteiro de pesquisadores que trabalhavam com arte por uma perspectiva sociológica. Em 1985, ela organizou, em Marselha, o primeiro simpósio de sociologia da arte ${ }^{17}$. Bourdieu estava ausente dessa iniciativa. Entre seus seguidores, havia alguns no-

16 Nascida em 1932, Claudine Herzlich trabalhou com Serge Moscovici no CNRS. Tornou-se professora da EHESS em 1985 e no ano seguinte inaugurou o Centre de Recherche Médecine, Science, Santé et Société (CERMES), que dirigiu até 1998. Entre suas publicaçōes, destacamos o livro assinado em coautoria com Philippe Adam, Sociologie de la maladie et de la médecine (Armand Colin, 2005).

17 O congresso de Marselha originou uma publicação coletiva com os trabalhos aí apresentados, sob a coordenação de Raymonde Moulin. Ver: Moulin, 1986. 
mes presentes, tais como Remy Ponton ${ }^{18}$ e Nathalie Heinich ${ }^{19}$, além de Jean-Claude Passeron, colaborador preferido de Bourdieu, com quem desenvolvera uma verdadeira relação de coautoria, mas de quem, nessa época, já estava distanciado. Como Passeron era natural de Marselha, a cidade foi escolhida para sediar o evento. Institucionalmente, a sociologia $\mathrm{da}$ arte foi assim construída, sem a presença de Pierre Bourdieu e sob a liderança de Raymonde Moulin. Naquela área, a França tornava-se pioneira, sem nenhuma tradição rival no mundo.

O desenvolvimento da sociologia da arte ocorreu de modo progressivo e paralelamente a um crescente interesse da sociedade pelos temas da arte e da cultura, mas sempre de modo secundário em relação a outras áreas temáticas mais centrais, e sem que Bourdieu - que era um nome maior na sociologia, como indica sua eleição para o Collège de France em 1981 - tenha tido papel decisivo para tanto. A partir de 1985, com o congresso organizado em Marselha, já era possível identificar os contornos de um domínio disciplinar autônomo. Quatro seçóes indicavam a agenda de pesquisas específicas da área: Políticas e instituições culturais; Profissóes e mercados artísticos; Públicos e percepção estética; e, por fim, Uma sociologia das obras é possível?

\section{Bourdieu e a sociologia da arte depois de sua institucionalização (após 1985)}

Após meados dos anos 1980, tempo que coincide com o reconhecimento da importância do congresso levado a cabo em Marselha em 1985, a sociologia da arte conheceu transformações significativas. Até o início da década de 1990, pode-se dizer que as mudanças foram limitadas aos trabalhos, por um lado, de Pierre Bourdieu e, de outro lado, de Raymonde Moulin, ambos desempenhando papéis centrais. Os dois publicaram no mesmo ano, 1992, livros fundamentais para a área: L'artiste, l'institution et le marché, de Moulin; e As regras da arte. Gênese e estrutura do campo literário (Les règles de l'art. Genèse et structure du champ littéraire), de Bourdieu (1992). Novamente, como nos anos 1960, percebe-se uma coincidência nas datas de publicação dos autores, o que tornou a ocorrer no princípio da década de 1990. Vale ressaltar que, no caso de Bourdieu, se tratava de um retorno notável a um objeto (arte) do qual ele havia se afastado por certo tempo.

Diferentemente de L'amour de l'art, que constitui um trabalho fulgurante, equilibrando uma forte perspectiva empírica com um desenvolvimento teórico de relevo, As regras da arte parece menos inovador, dado que seu conteúdo é menos original e, do ponto de vista metodológico, aplica um modelo preexistente. Assim, ao contrário de L'amour

18 Discípulo de Bourdieu, Rémy Ponton desenvolveu estudos nas áreas de sociologia dos intelectuais, da literatura e das práticas culturais. Sobre suas publicaçōes, consultar: <http://www2.univ-paris8.fr/sociologie/?page_id=3>. Acesso em: 15 fev. 2019.

19 Nathalie Heinich é uma das sociólogas da arte mais produtivas e atuantes na França hoje. Realizou seu doutorado sob a orientação de Pierre Bourdieu, concluído em 1981. Logo ingressou como pesquisadora no CNRS, instituição a que se mantém vinculada, ao lado da EHESS, da qual faz também parte. Entre suas muitas obras, destacamos: Du peintre à l'artiste. Artisans et académiciens à l'âge classique (Éditions de Minuit, 1993); Le Triple Jeu de l'art contemporain. Sociologie des arts plastiques (Éditions de Minuit, 1998); e Le Paradigme de l'art contemporain. Structures d'une révolution artistique (Gallimard, 2004). 
de l'art, que trouxe um aporte incontornável para todo o pesquisador interessado nas relaçóes entre arte e seus públicos, independentemente da escola de pensamento a que se filie, a contribuição de $A s$ regras da arte foi recebida, na França, como mais pontual. O mesmo não ocorreu, porém, no Brasil, onde, como bem demonstraram Bortoluci, Jackson e Pinheiro Filho (2015, p. 235), o livro está entre os de maior impacto do autor, tão presente nos diversos estudos sobre arte e cultura realizados no país que pode ser visto como a referência da disciplina no Brasil, centralizando as balizas metodológicas das pesquisas na área ${ }^{20}$.

Desde os anos 1990, anunciava-se ainda como iminente a publicação de Manet. Une révolution symbolique (Bourdieu, 2013), o que, porém, só viria a ocorrer em 2013, como obra póstuma e inacabada. Vale assinalar que, ainda na década de 1990, a influência de Howard S. Becker era cada vez mais evidente, graças à obra Les mondes de l'art (Becker, 1988), o que de certo modo vinha a completar as contribuiçóes de Pierre Bourdieu e Raymonde Moulin. Essa influência crescente de Becker na sociologia da arte francesa e internacional em parte esteve ligada à iniciativa de certos sociólogos que, em 1991, lançaram o Groupe de Recherche/ Grupo de Pesquisa Oeuvres, Publics, Société/Obras, Públicos, Sociedade (OPUS) ${ }^{21}$, que desempenhou papel relevante no fortalecimento da sociologia da arte na França ao longo dos anos 1990 e começo dos 2000, redesenhando os contornos dos seus objetos e metodologias (Péquignot, 2009).

Pierre Bourdieu desfrutava amplo reconhecimento nesse espaço, mas ele e seus seguidores voltados às pesquisas sobre arte estiveram ausentes de mais essa iniciativa. Enquanto isso, Raymonde Moulin adotou uma atitude mais reservada, participando por vezes, mas demonstrando reticências quanto ao projeto de desenvolver uma sociologia das obras. Bourdieu — e igualmente seus colaboradores - , que já havia negligenciado, como se viu, as iniciativas levadas a cabo durante a década de 1980 para institucionalizar a sociologia da arte, também não se engajou nos debates em torno de uma sociologia das obras, ainda que em seus escritos tenha dado atenção a esse tema. De qualquer modo, novamente ele estaria ausente de um movimento que se caracterizou por um dinamismo institucional importante. De certa maneira, a influência de Pierre Bourdieu sobre a sociologia da arte francesa diluiu-se com a recomposição desse campo a partir dos anos 1990. A sociologia da arte alargou-se consideravelmente, aproximou-se da sociologia da cultura e aumentou de forma expressiva o número de participantes.

Convém então restituir brevemente esse percurso da sociologia da arte francesa, que assinalou transformaçôes significativas depois dos anos 1960. A principal evolução que procuramos pontuar foi a de que a sociologia $\mathrm{da}$ arte francesa se aproximou da sociologia da cultura. Hoje é possível fazer sociologia

20 É importante frisar que, no Brasil, diversos outros autores são lidos e tidos como referência para pensar artes e cultura, tais como T. Adorno, Michel Foucault, Néstor García Canclini, Edward Said, Raymond Williams, Homi Bhabha, Alfred Gell, Andreas Huyssen, Norbert Elias, entre tantos outros, mas quando se pensa em sociologia da arte o termo praticamente é visto como um sinônimo das pesquisas desenvolvidas por Pierre Bourdieu.

21 Bruno Péquignot, professor da Université Paris III, e Alain Pessin, professor da Université Grenoble, foram os dois principais atores no interior do Groupement de Recherche Opus a procurarem desenvolver uma sociologia das obras. 
da arte e da cultura, o que náo era o caso na década de 1990. Por isso os sociólogos bourdiesianos podem ser incluídos na sociologia da arte, cujos contornos se tornaram menos estreitos. Esse novo conjunto que constitui a sociologia da arte e da cultura se tornou um dos principais campos de pesquisa sociológica na França, o que pode ser demonstrado pelo grande número de teses de doutorado defendidas nesse domínio.

Entre as recomposiçóes da área, pode-se assinalar, por exemplo, o caso da sociologia da literatura, que há 20 anos constituia um espaço muito distinto da sociologia da arte, mas que hoje pode ser vista como um de seus subcampos. Na classificação proposta por Bruno Péquignot, em 2009, no livro Sociologie des arts, $o$ autor distingue seis grandes temas centrais na agenda da sociologia da arte francesa: instituiçôes e políticas culturais; mercados e profissóes artísticas; recepção e legitimação; práticas e consumos culturais; as diferentes formas de expressão artística; e a ciência das obras. Dado que existem mudanças externas que impactam a própria sociologia da arte, hoje poderíamos também incluir temas tais como gênero e globalização nesse cenário, os quais vêm afetando as sociedades nos últimos 20 anos e suscitando respostas por parte da sociologia ${ }^{22}$. Vale frisar que a perspectiva bourdiesiana está desigualmente representada nos diferentes temas precedentes que dominam, hoje em dia, a agenda de pesquisas na área.

Não obstante, Bourdieu tornou-se muito presente, de maneira incontestável, a partir dos anos $1990 \ldots$ no exterior! De modo breve, pode-se dizer que a tradição francesa que se estruturou entre os anos 1960 até sua plena institucionalização nos anos 1980 influenciou outros países, em primeiro lugar os Estados Unidos. Os autores que tiveram papel ativo nessa difusão, em geral, eram sociólogos que dominavam o francês e que puderam seguir, desde o início, a emergência desse domínio na França, lendo os textos assim que publicados e, por vezes, atuando em sua tradução. É o caso de autoras como Vera Zolberg ${ }^{23}$, Priscilla Ferguson $^{24}$ e Diana Crane ${ }^{25}$, as quais foram fundamentais para divulgar a sociologia da arte francesa nos Estados Unidos, todas elas dotadas de amplo conhecimento das línguas francesa e inglesa. As duas primeiras foram particularmente tocadas pelas teorias de Pierre Bourdieu, o que foi decisivo

22 A questão do gênero está presente em um dos capítulos do livro de Alain Quemin (2013), Les stars de l'art contemporain. Sobre esse ponto, ler o texto já mencionado do autor, publicado pela Cambridge University Press. Também diversos trabalhos de Ana Paula C. Simioni são dedicados à questão das relaçôes entre arte e gênero. Especialmente, ver: Profissão artista (2008), mas também "Bordado e transgressão: questôes de gênero na arte de Rosana Paulino e Rosana Palazyan”, publicado na revista Proa, em 2010.

23 Vera Zolberg defendeu seu doutorado em Sociologia na University of Chicago e foi professora da New School for Social Research. Teve papel crucial na introdução de Bourdieu nos Estados Unidos. É autora de várias publicaçóes importantes. Entre elas, destacamos: Zolberg, 1990.

24 Muito marcada pela leitura de Bourdieu, Priscilla Fergusson formou-se em Literatura Francesa, depois orientando-se para a Sociologia. Foi professora da Columbia University.

25 Diana Crane é professora emérita da University of Pennsylvania. Autora de diversos livros importantes na área de sociologia da arte e da moda, entre os quais destacamos: The Transformation of Avant-Garde (1987). Mais informaçôes em: <https://sociology.sas.upenn.edu/d_crane>. Acesso em: 21 mar. 2019. 
para a sua acolhida nos Estados Unidos ${ }^{26}$. Por outro lado, Howard S. Becker, autor de uma obra tão inovadora como Les mondes de l'art, jamais escondeu ter aprendido o francês para ler os trabalhos de Raymonde Moulin, especialmente Le marché de la peinture en France, em uma época em que o livro ainda não estava traduzido para o inglês, e, como ele frisou, não tinha muita simpatia pela sociologia de Pierre Bourdieu, a qual qualificava como grande teoria. Porém, foram claramente os trabalhos de Bourdieu, muito mais do que os de $\mathrm{Mou}-$ lin, que encontraram ecos no estrangeiro.

A internacionalização da sociologia da arte francesa efetuou-se, portanto, em grande parte graças à ligaçáo privilegiada com os Estados Unidos, mas também encontrou respaldo nas instituiçóes internacionais, tais como, primeiramente, a Association Internationale de Sociologie. Embora esta tenha sido criada em 1949, o Comitê de Pesquisas em Sociologia da Arte (no 37) só foi fundado muito mais tarde, em 1979. A título de comparação com áreas próximas, o Comitê de Pesquisa em Sociologia da Comunicação (no 14) foi inaugurado em 1959, e o Comitê de Pesquisas em Lazer ( $\left.n^{\circ} 13\right)$ remonta a 1970, quase dez anos antes do dedicado à arte. Raymonde Moulin fazia parte do grupo que havia fomentado o comitê e que acabou por ser oficialmente reconhecido em 1980. Após um primeiro momento em que esse comitê se limitara à atuação dos coordenadores (1981-82), as estruturas próprias a ele foram efetivadas mesmo em 1982. Entre 1982 e
1986, o comitê foi presidido pelo húngaro Iván Vitányi e tinha como vice-presidente o francês Antoine Hennion ${ }^{27}$, incluindo ainda no seu staff Raymonde Moulin e Vera Zolberg, que ocupava o cargo de secretária e acabou exercendo a presidência entre $1990 \mathrm{e}$ 1994. Zolberg era especialmente atuante no comitê, o que colaborou para difundir em âmbito internacional a perspectiva de Bourdieu, da qual era particularmente próxima.

\section{A centralidade de Bourdieu na sociologia da arte brasileira}

O Brasil constitui um dos países que mais contribuem para o impacto internacional da produção de Pierre Bourdieu. Partindo-se do estudo das traduçóes, que podem ser consideradas como um índice relevante de internacionalização, o português desponta como uma das cinco línguas em que mais títulos do autor foram publicados, com 28 obras, depois do alemão, espanhol, inglês e italiano. Segundo a análise de Gisèle Sapiro e Bustamante (2009, p. 12):

Germany, Spain, the United Kingdom and the United States appear to be the leading countries for Bourdieu's international reception (more than 30 titles translated), followed by Italy and Brazil (between 21 and 30). These six countries account for almost half of Bourdieu's titles in translation published in different countries $(47.7 \%)$. They are central in Bourdieu's international reception.

26 Sobre a importância dos trabalhos de Crane e Zolberg para a sociologia da arte, incluindo seus impactos no Brasil, ler: Bueno, Sant’anna e Dabul, 2018, especialmente as páginas 277-279.

27 Antoine Hennion é um sociólogo da arte francês contemporâneo, especialista em sociologia da música e teorias da mediação. Concluiu seu doutorado em 1991, na mesma época em que terminou a formação em Musicologia na Université de Paris IV. É professor no Centre de Sociologie de l'Innovation. Entre suas muitas produçôes, destacamos: La passion musicale. Une sociologie de la médiation (2007). 
Além das traduçôes, Bourdieu está entre os três autores mais citados pelos pesquisadores brasileiros da área de ciências humanas e sociais, atrás apenas de Foucault e Althusser (Bortoluci, Jackson e Pinheiro Filho, 2015, p. 217). As primeiras obras traduzidas para o português no Brasil foram coletâneas, como: A economia das trocas simbólicas, organizada por Sergio Miceli em 1974, e Pierre Bourdieu: sociologia, organizada por Renato Ortiz em 1983. Ambos os organizadores sáo intelectuais nacionais que, além de outras contribuiçóes, desempenharam papéis notáveis para a disseminação das teorias de Bourdieu, as quais deveriam ser lidas, compreendidas e aplicadas tendo em vista as particularidades do contexto brasileiro. Ainda nesse primeiro momento de recepçáo, que grosso modo pode ser compreendido como as décadas de 1970 e 80, o título A Reprodução, assinado por Bourdieu e Passeron, teve grande circulação no país, especialmente na área de educação (Catani, 2002).

A recepção primeira de Bourdieu no Brasil se deu muito mais com base na compreensão de que constituía um modelo analítico geral, inovador na medida em que se mostrava capaz de transcender a dicotomia representada pela oposição entre teorias estruturalistas $\times$ teorias da ação, por meio de noções como campo e habitus, do que propriamente como um sociólogo especializado em uma ou outra área do saber. Nesse sentido, ecoava no país a percepção de Howard
S. Becker, de que se tratava de uma grande teoria. De certo modo, essa ambiçáo totalizante contribuiu para sua ampla disseminação, pois o método poderia (e/ou deveria) ser lido por todos os pesquisadores em humanidades, independentemente dos objetos específicos a que se dedicavam, no entanto essa mesma pretensão de universalidade fez com que outras disciplinas mais vinculadas tradicionalmente às especificidades intrínsecas aos objetos a que se dedicam o vissem com estranheza, quando não com ressalvas. Não é exagero dizer que historiadores da arte ou críticos literários, entre outros, possuíam (e de certa maneira ainda possuem) reticências com esse caráter geral do método, visto como excessivamente determinista, ou incapaz de perceber as especificidades internas a cada meio expressivo ${ }^{28}$.

É interessante notar que, entre os três primeiros mediadores fundamentais na importação de Bourdieu para o Brasil, se contam três sociólogos da cultura (área que, de modo geral, no Brasil engloba a sociologia da arte). Primeiramente o já mencionado Sergio Miceli, que realizou seu doutorado sobre intelectuais e classes dirigentes no Brasil (1978), sob a orientação direta de Pierre Bourdieu. A tese, publicada em livro pela editora Difel em 1979, apresenta um estudo morfológico e prosopográfico dos intelectuais e escritores atuantes em um dos mais fecundos momentos da cultura brasileira, a Era Vargas (1937-1945), algo absolutamente

28 Um documento muito significativo a esse respeito é o prefácio que Antonio Candido redigiu para o livro de Sergio Miceli originalmente publicado em 1979 e republicado em 2005 com o título Intelectuais e classes dirigentes no Brasil em que sublinha, a despeito dos méritos do livro, a "arriscada tendência contemporânea para a desmitificação e as explicaçôes por meio daquilo que está por baixo, escondido da consciência e da observação imediata", ou, ainda, considera a posição assumida por Miceli como "polêmica", porque "talvez ele "julgue' mais do que seria preciso". Nitidamente o célebre crítico literário paulista se incomoda com a visada sociológica, como assinala de modo claro na seguinte passagem: "A respeito caberia uma observaçáo sobre o perigo das análises desse tipo, que podem ser qualificadas para simplificar de 'ideológicas'. Falo do perigo de misturar desde o começo do raciocínio a instância de verificação com a instância de avaliação" (Candido, 2001, p. 71-72). 
inovador do ponto de vista metodológico no Brasil de então. Outra dimensão de impacto da obra diz respeito à forma como se permitiu pensar na relação entre produção cultural e elites políticas no país, colocando em questão o caráter supostamente inefável da produção artística, geralmente vista como um produto do talento, do dom individual. Vale observar ainda que Miceli baliza suas análises em farto material empírico, biográfico e literário e prescinde, como já se verificou, de utilizar uma noçáo cara a Bourdieu, a de campo, por entender que as particularidades da produção cultural do Brasil varguista exigem a utlização de categorias próprias (Bortoluci, Jackson e Pinheiro Filho, 2015, p. 229). Após o estudo sobre os escritores na Era Vargas, Miceli publicou outros trabalhos importantes para a sociologia da arte no Brasil, especialmente no que tange às particularidades do modernismo nacional. Entre eles, ressalta-se Imagens negociadas (1996), dedicado aos retratos da elite varguista encomendados a Cândido Portinari; e Nacional estrangeiro: história social e cultural do modernismo artístico em São Paulo (2003), ambos editados pela Companhia das Letras.

Já Renato Ortiz se formou em Sociologia na França, na Universidade de Paris VIII (1972), e desenvolveu seu doutorado na EHESS, sob a orientação de Roger Bastide (La mort blanche du Sacieu Noci), concluída em 1975. A escolha por Bastide era plenamente compreensível. Tratava-se de um nome muito conhecido pelos brasileiros, pois, chegando ao Brasil para substituir Claude Lévi-Strauss em 1937, acabou assumindo a direção da Cadeira de Sociologia I, que era a mais prestigiosa no curso de Ciências Sociais e Políticas oferecido pela USP até
1954, quando voltou para a França. No decorrer dos 16 anos em que esteve à frente da cátedra, formou um conjunto de intelectuais notáveis, entre os quais se incluem Maria Isaura Pereira de Queiroz, Gilda de Mello e Souza e Florestan Fernandes ${ }^{29}$. Foi Bastide o primeiro a ministrar um curso em sociologia da arte no país, em 1940, o qual mais tarde foi publicado como livro intitulado Arte e sociedade, obra pioneira nesse campo de estudos (Pinheiro Filho, 2006).

No entanto, embora Bastide tenha realizado publicaçóes fundamentais, atuado como docente e formado um conjunto expressivo de intelectuais de prestígio, seu legado náo foi suficiente para manter as artes e a cultura como temas centrais para a sociologia no Brasil, não chegando $\mathrm{a}$ institucionalizar a disciplina. Conforme as análises de Pulici (2004) e Jackson (2007), a substituição de Bastide por Florestan Fernandes em 1954 trouxe uma profunda reorganização no modo de pensar, de fazer e de hierarquizar a sociologia na USP. A ênfase em temas do presente, tidos como socialmente relevantes, ligados à dinâmica da sociedade capitalista e industrial, aliados a uma valorização extrema da pesquisa empírica e a um rigor metodológico quase cientificista, terminou por desvalorizar os estudos sobre tradiçóes brasileiras, cultura, literatura, artes ou mesmo voltados à teoria pura, vistos então como diletantes, sem impacto social e científico imediato.

Ecos da influência de Bastide continuaram a ser notados em intelectuais vinculados à cadeira de Sociologia II, tais como Ruy Coelho, Duglas Monteiro, Fernando Albuquerque Mourão e, sobretudo, Maria Isaura Pereira de Queiroz, que desde 1958

29 A respeito dos herdeiros de Bastide, ler: Braga, 2000. 
ocupara a direção da cadeira e liderava também o Centro de Estudos Rurais e Urbanos (CERU). A despeito da qualidade intelectual de cada um deles, as diversidades temáticas e metodológicas a que se dedicaram não permitiam que formassem uma escola, o que não seria em si um óbice, mas, quando comparado à coesão de princípios, objetivos, métodos e práticas de conduta da cadeira de Sociologia I, acabou por enfraquecer ainda mais tais tendências, que, ao longo do tempo, acabaram por se tornar marginais dentro do departamento. Assim, o projeto iniciado por Bastide de implantar uma sociologia da cultura e da arte no Brasil não ocorreu até ao menos os anos 1970.

Ao retornar à França, Roger Bastide tornou-se diretor do Centro de Psiquiatria Social na École Pratique des Hautes Études e, em 1959, foi eleito professor de Etnologia na Sorbonne. Embora não ocupasse uma posiçáo institucional marginal, não chegou a atingir a notoriedade que teve no Brasil. Denys Cuche (2008) afirma que diversas razóes contribuíram para isso: ter começado relativamente tarde a carreira na França; as suas principais obras terem sido escritas em português, permanecendo inacessíveis por muito tempo para a maior parte do público leitor de seu país; e, especialmente, seus temas de pesquisa (relações interétnicas e contatos culturais) não eram vistos como tão importantes, numa época em que as hierarquias de objetos colocavam no cume os estudos sobre classes sociais e relaçóes de trabalho também em sua terra natal. A redescoberta da importância de Bastide, mesmo no campo da sociologia da arte, é um fenômeno recente.

No entanto, Bastide despontou como o orientador natural para o projeto de douto- rado de Renato Ortiz, realizado na França, que culminou em A morte branca do feiticeiro negro, dedicado à umbanda, tendo em vista seu conhecimento ímpar sobre religiōes afro-brasileiras ${ }^{30}$. Ao voltar ao Brasil, em 1977 Ortiz participou da reorganização dos quadros acadêmicos em diversas universidades brasileiras que se desenvolviam naquele turbulento período, passando pela Universidade Federal da Paraíba, depois pela Universidade Federal de Minas Gerais, depois fixando-se em São Paulo, inicialmente na PUC-SP até ingressar na UNICAMP, em 1988, onde se encontra até hoje.

Do ponto de vista de suas produçóes, a rigor, a primeira contribuiçáo para a área de sociologia da arte e da cultura foi a organização da já mencionada coletânea de textos de Bourdieu, porém é preciso destacar o impacto de A moderna tradição brasileira, publicado em 1988, na medida em que, nesse pioneiro estudo sobre a indústria cultural no Brasil, o autor dialoga criticamente com uma noçấo cara à teoria bourdiesiana: a das lógicas distintas que regem o mercado de bens simbólicos. Segundo Bourdieu (1974), tal mercado específico assenta-se na contraposição entre a esfera de produção de bens de circulação ampliada à esfera de bens de circulação restrita. Ou seja, há oposição absoluta entre as posiçóes culturais relativas à indústria cultural e à cultura erudita $\mathrm{e}$, conforme a perspectiva bourdiesiana, caberia a esta última a imposição dos critérios de legitimidade no campo. Todavia, a pesquisa de Ortiz, documentada por meio de rico material empírico e estatístico e análise de casos, demonstra que tal dicotomia inexiste no Brasil dos anos 1940-50; e mais, o autor evidencia que uma promoção efetiva de um mercado de bens simbólicos

30 Ler entrevista de Renato Ortiz publicada em Bastos, Loureiro e Rego, 2006, p. 317-318. 
ocorrera aqui graças ao forte estímulo promovido pelo Estado autoritário, durante os anos 1960 e 70 . Esses dois pontos levantados desafiam premissas caras às teorias desenvolvidas por Bourdieu (Ortiz, 1988, 2013). Com efeito, com essa obra Renato Ortiz deu ensejo a uma escola de estudos sobre as especificidades da indústria cultural no Brasil, dedicada a analisar os modos como as esferas de bens simbólicos e econômicos se interconectam num país cujo processo de modernização é ao mesmo tempo acelerado, pujante e incompleto $^{31}$.

Vê-se que tanto Miceli quanto Ortiz possuem uma postura comum que merece ser salientada: não apenas introduziram as teorias, os conceitos e a metodologia de Bourdieu no Brasil, mas fizeram-no refletindo sobre o modo como as configuraçôes específicas da realidade local, mormente as relativas à produção artística e cultural, interpelam a própria teoria. Ou seja, não se tratou jamais de uma importação mimética das teses de Bourdieu, mas sim de concepçóes que deveriam estar sujeitas, desde sempre, às particularidades e aos ajustes exigidos por dada experiência.

Fundamental ainda para se pensar no desenvolvimento de uma sociologia da arte no Brasil é o livro Arte, privilégio $e$ distinção, do professor vinculado por muito tempo à Fundação Getulio Vargas, de São Paulo, José Carlos Durand ${ }^{32}$, publicado inicialmente pela editora Perspectiva em 1989, após a realização de um pós-doutorado na França supervisionado por Pierre Bourdieu. Entre as três obras citadas, de Renato Ortiz, de Sergio Miceli e de Durand, esta é efetivamente a que mais se dedica a investigar a formação e as particularidades de um campo artístico no Brasil, isso porque o livro de Miceli aborda os escritores, estando mais próximo de uma sociologia da literatura, ao passo que o de Renato Ortiz se consagra à indústria cultural e seria classificável, se assim fosse exigido, como sociologia da cultura ${ }^{33}$.

O livro de Durand (1989) é, pois, o primeiro trabalho sociológico consagrado às artes visuais pelo referencial de Pierre Bourdieu. Por intermédio de uma perspectiva histórica de longa duração, abordando desde a formação de um sistema artístico no período imperial brasileiro até o desenvolvimento de um mercado artístico nos anos 1960/70, o autor traça a gênese de nosso campo artístico, também bastante atento às suas particularidades. Entre outros aspectos, nota-se a

31 Os impactos dessas reflexôes podem ser vistos nas trajetórias e obras de alguns de seus orientandos cujos trabalhos geralmente incidem sobre temas correlatos à indústria cultural, como televisão, cinema, turismo, moda, publicidade, mas também por vezes música, artes plásticas (e, portanto, sociologia da arte). Entre eles, por ordem de doutoramento: José Mario Ortiz Ramos (1990), Jorge Noel Ribeiro (1992), Maria Lucia Bueno (1995), Maria Celeste Mira (1997), Jorge Roberto Zan (1997), Edson Farias (2001), Anderson Retondar (2003), Celina Borges (2003), Rafael dos Santos (2003), Mariana Barreto Lima (2009), Rosario Radacowich (2011), Michel Nicolau (2012), Michele Miquetti (2012) e Marcelo Ribeiro (2018). Mais informaçóes em: <http://lattes.cnpq.br/8800427022722082> Acesso em: 20 mar. 2019. Outro dado relevante é que o livro possui 2.516 citaçóes segundo o Google Scholar. Mais informaçôes em: <https://scholar.google.com/citations? user=43A-6JgAAAAJ\&hl=en\&hl=pt-BR>. Acesso em: 5 mar. 2019.

32 Para saber mais sobre os autores mencionados, ler: Rego, Loureiro e Bastos, 2006.

33 Não estamos aqui advogando barreiras rígidas entre as áreas. Ao contrário, posto que as pesquisas e reflexôes em cada um desses domínios são frutíferas para as demais, mas também se nota que cada um desses objetos posta problemas próprios em termos de linguagem, tradiçóes interpretativas, convençốes etc., exigindo do pesquisador familiaridades com os materiais expressivos e com a história interna de cada um desses domínios. 
constante presença do campo político para a afirmação do campo artístico, o que desafia a própria noção de autonomia, tão cara à perspectiva bourdiesiana. Se de fato Bourdieu é uma referência para o trabalho, não se pode esquecer que a obra é igualmente marcada pelos livros e pesquisas de Raymonde Moulin, de maneira especial Le marché de la peinture en France. Com efeito, uma das dimensôes fundamentais desse livro é o modo como o autor se atenta para as dinâmicas do mercado artístico em cada um dos períodos abordados, problemática que passou a despertar mais atenção dos estudiosos recentemente (já no século XXI), o que mantém o livro uma referência atual. Embora Durand, em virtude de ter seu vínculo profissional atrelado à Fundação Getulio Vargas, instituição que, a despeito de seu grande prestígio, náo investira até muito recentemente em pós-graduaçóes lato sensu, não tenha deixado, portanto, orientandos diretos, seu livro é uma referência incontornável nos estudos sobre arte e sociedade no Brasil.

Pode-se mesmo dizer que o livro de Durand (1989) se articula, em termos teóricos e metodológicos, por meio de um diálogo bastante equilibrado entre Bourdieu e Moulin, ambos tidos como referências igualmente fecundas para se pensar uma sociologia da arte adequada ao caso local. Esse equilíbrio reflete também a situação de uma sociologia da arte especificamente francesa, como já se viu, em que Pierre Bourdieu era um dos, mas não o único grande autor. Não obstante, essa diversificação do campo da sociologia da arte na França, internalizada na presente obra de
Durand (1989), provavelmente estimulada pelo campo de discussóes derivado do objeto (artes visuais) a que se dedicou, evapora-se no Brasil. Novamente as traduçóes podem ser tomadas como índices dessa situação.

Há apenas um livro de Raymonde Moulin traduzido para o português, $O$ mercado da arte: mundializaçáo e novas tecnologias, e somente em 2007! Ou seja, 40 anos após a publicação de Le marché de la peinture en France vemos enfim uma obra da autora ser traduzida, e infelizmente não se trata de um dos seus trabalhos mais reputados. Com isso, os títulos de Moulin não podem ser facilmente acessados no Brasil, tendo em vista as barreiras linguísticas (cada vez se lê menos francês no país) e outro impeditivo não negligenciável: o alto custo dos livros importados.

Não é apenas a obra de Moulin que permanece pouco conhecida. Mesmo o clássico livro de Howard S. Becker Art worlds, fundamental para a própria sociologia da arte como disciplina, circula pouco entre os leitores brasileiros em geral, posto que ainda não está traduzido. Embora seja um autor lido pelos estudantes de Ciências Sociais no país, em função das publicaçóes de diversos de seus títulos, especialmente aqueles dedicados às questóes metodológicas, o autor é ainda não tão reconhecido como um sociólogo da arte $^{34}$. Também apenas nos últimos dez anos vimos surgir traduçôes de sociólogos da arte norte-americanos, tais como Vera Zolberg (Para uma sociologia das artes, pela editora Senac em 2006) ou Diana Crane (Ensaios de moda, arte e globalização cultural, pela edito-

34 Os livros de Howard Becker traduzidos para o português são: Uma teoria da ação coletiva (Zahar, 1977); Segredos e truques da pesquisa (Zahar, 2007); Outsiders (Zahar, 2008); Falando da sociedade (Zahar, 2009); e Truques da escrita (Zahar, 2015). Existe uma edição de Mundos da arte publicada em Lisboa pela editora Livros Horizonte em 2010, que está esgotada, adquirível apenas por sites de livros usados em valores inacessíveis (em fevereiro de 2019, R\$ 450 no site Estante Virtual). 
ra Senac em 2011), ambas em grande parte intermediadas pela atuaçáo da socióloga da arte Maria Lucia Bueno ${ }^{35}$. Diversos outros autores permanecem não apenas náo traduzidos, mas de leitura circunscrita a poucos cursos de pós-graduação na área, tais como Pierre-Michel Menger, Antoine Hennion, Tia DeNora, Nathalie Heinich, Bruno Péquignot, Jean-Pierre Esquenazi e mesmo um dos autores do presente artigo, Alain Quemin. Desta feita, pode-se dizer que Pierre Bourdieu acaba exercendo influência muito central na sociologia da arte brasileira, sofrendo menos a concorrência de pares intelectuais, como mostramos ocorrer na França.

Nos últimos dez anos, os grupos de trabalho na Sociedade Brasileira de Sociologia e na ANPOCS, bem como as traduçôes, assinalam uma diversificação metodológica, uma proliferação de autores e de títulos citados pelos pesquisadores, o que sinaliza um adensamento da pesquisa em sociologia da arte no Brasil. Mapear tal produção em um país tão grande e com uma rede institucional tão vasta é tarefa que transcende as possibilidades deste artigo. A título de exemplo, um levantamento na base de teses e dissertaçôes da CAPES com a palavra-chave sociologia da arte trouxe 1.125.650 resultados, número evidentemente excessivo. Refinando os mecanismos de busca de modo a concentrar as teses apenas em programas de Sociologia, chegamos a 11.718 títulos, o que é bastante significativo. Chama ainda atenção que há 1.948 orientadores vin- culados a essa área, os quais estáo divididos entre 47 instituiçóes diferentes. Entre estas, as que concentram a maior quantidade de produções na área citada são: PUC-SP (1.406 teses), USP (957), UNICAMP (769) — as três localizadas no estado de São Paulo - e, em quarto lugar, a UFRJ $(537)^{36}$.

A mesma base de dados reitera a centralidade de Bourdieu, já verificada no estudo das traduçóes. Uma pesquisa com base em palavras-chave combinadas com os filtros citados trouxe os seguintes números: Pierre Bourdieu (8.092), com mais que o dobro de citaçôes que Howard Becker (4.055), o qual também supera Theodor Adorno (2.450) no campo da sociologia. A presença de Raymonde Moulin é, comparativamente, tímida (390), embora maior do que a de Nathalie Heinich (160), Diana Crane (6) e Vera Zolberg (1). Outros sociólogos da arte como Tia DeNora não apareceram na pesquisa. Esses dados são indicativos do grau de influência desigual desses autores no Brasil, embora não sejam capazes de identificar o nível de mobilização de cada um deles na urdidura metodológica dos trabalhos.

A acolhida das obras de Pierre Bourdieu é também desigual, e vale notar que ao longo de sua trajetória o modo de compreender as relaçôes entre agência e determinação no campo da construção cultural, incluindo a artística, variou de um maior determinismo (como em $A$ reprodução) até a maior margem de liberdade para o agente (como na

35 Socióloga da arte muito atuante no Brasil, Maria Lucia Bueno vem organizando grupos de trabalho na área nos principais congressos do país (Sociedade Brasileira de Sociologia e ANPOCS). Além disso, quando esteve à frente da coordenaçấo da Pós-Graduaçấo em Moda, pelo Serviço Nacional de Aprendizagem Comercial (Senac) (a primeira da América Latina), organizou a tradução de diversos livros fundamentais para a sociologia da arte e moda no Brasil. Entre suas publicaçôes, destacamos: Bueno, 2012. Mais informaçōes disponíveis em: <http://www.uff. br/ppgcso/docentes/permanentes/maria-lucia-bueno/>. Acesso em: 5 mar. 2019.

36 Tais dados foram obtidos por meio de uma pesquisa na base de dissertaçóes e teses da CAPES, disponível em: $<$ https://catalogodeteses.5/capes.gov.br/catalogo-teses/\#!/>. Acesso em: 16 maio 2019. 
obra póstuma, Manet. Une révolution symbolique, ainda náo traduzida para o português $)^{37}$. As regras da arte. Gênese e estrutura do campo literário é o livro que tem exercido mais impacto na sociologia da arte brasileira, constrastando com o reconhecimento de L'amour de l'art, na França ${ }^{38}$. Como se vê, países periféricos ou semiperiféricos, como o Brasil, podem ser bastante significativos para dotar de centralidade determinadas obras de autores que, em seus países de origem, enfrentam a concorrência entre seus pares intelectuais. Em um período em que a legitimidade das ideias e dos conceitos é também auferida por meio de indicadores de impacto cada vez mais globais, podemos sugerir que a recepção de Bourdieu na sociologia da arte brasileira, em que ele reina de modo soberano, colabora para a perpetuaçáo de sua condição de referência internacional, de centro ou de fundador da sociologia da arte francesa, mesmo que na França as coisas náo sejam exatamente assim.

\section{Conclusão}

Nos anos 1960, Pierre Bourdieu foi um autor fundamental para a renovaçáo e o delineamento da sociologia da arte contemporânea na França. Especialmente a obra L'amour de l'art teve grande impacto dentro e fora do campo acadêmico, sendo adotada por diversas instituiçóes do mundo da arte como grande referência para repensar suas próprias açóes. No entanto, como pretendemos ter demonstrado, ao longo da década de 1980 e sobretudo 90, essa centralidade foi sendo atenuada. Para tanto, contribuíram uma série de questôes. Houve um adensamento institucional da sociologia da arte no interior do sistema acadêmico francês, por meio de açôes como o congresso de Marselha, a criaçáo do Grupo OPUS, entre outros, que apontam a pluralidade de autores e de metodologias em curso. A pessoa de Bourdieu esteve ausente de todas essas iniciativas, muito embora sua produção escrita tenha permanecido como referência. Tal ausência, possivelmente, tenha decorrido da estratégia adotada pelo autor de desenvolver um projeto intelectual bastante amplo, não atrelado a objetos específicos. Nesse sentido, como se afirmou no texto, Bourdieu não queria, e náo poderia, ser visto apenas como um sociólogo da arte, mas tal escolha também significou seu afastamento de um processo de adensamento, diversificaçáo e institucionalizaçáo de um campo de pesquisas que se tornou pioneiro no mundo e hoje pode ser visto como bastante complexo, ao menos na França.

Nos anos 1990, com a publicação de As regras da arte, Bourdieu retomou seus investimentos nesse campo, mormente na sociologia da literatura, em um momento em que outros autores também já se tornavam referências reconhecidas para a sociologia da arte, tanto em termos teóricos quanto metodológicos e, também, institucionais, como é o caso de Raymonde Moulin, Howard S. Becker, entre outros. No entanto, nesse mesmo período, a influência do autor tornou-se cada vez mais importante no exterior, em países como os Estados Unidos e também o Brasil, onde o livro mencionado desfruta gran-

37 A esse respeito, ler: King, 2000.

38 O artigo já citado de Sapiro e Bustamante (2009) deixa claro que As regras da arte recebeu muito mais traduçôes (19), enquanto L'amour de l'art muito menos (9). Mesmo a obra capital $A$ distinção foi versada para 14 línguas, e, vale notar, no Brasil isso ocorreu tardiamente. Esses dados sáo importantes para marcar o quanto o exterior foi decisivo para a difusáo e, portanto, para a centralidade, de um livro como As regras da arte. 
de centralidade. Assim, enquanto na França Bourdieu enfrentava certa concorrência intelectual, no exterior era alçado a representante solar da sociologia da arte contemporânea francesa. Nesse processo de construção da consagraçáo da sua obra, intelectuais de outros países tiveram importante papel de mediação, contribuindo fortemente para o reconhecimento de sua produçáo e por dotá-la de uma centralidade que, na França, era ameaçada por outros intelectuais que se dedicaram à construção dessa área disciplinar.

\section{Bibliografia}

BASTOS, Elide Rugai; LOUREIRO, Maria Rita; REGO, José Marcio. Conversa com Sociólogos Brasileiros. São Paulo: Editora 34, 2006.

BECKER, Howard S. Uma teoria da açáo coletiva. Rio de Janeiro: Zahar, 1977.

BECKER, Howard S. Les mondes de l'art. Paris: Flammarion, 1988.

BECKER, Howard S. Segredos e truques da pesquisa. Rio de Janeiro: Zahar, 2007.

BECKER, Howard S. Outsiders. Rio de Janeiro: Zahar, 2008.

BECKER, Howard S. Falando da sociedade. Rio de Janeiro: Zahar, 2009.

BECKER, Howard S. Mundos da arte. Lisboa: Livros Horizonte, 2010.

BECKER, Howard S. Truques da escrita. Rio de Janeiro: Zahar, 2015.

BORTOLUCI, José Henrique; JACKSON, Luiz C.; PINHEIRO FILHO, Fernando A. Contemporâneo clássico: a recepção de Pierre Bourdieu no Brasil. Lua Nova, n. 94, p. 217-254, 2015. http://dx.doi.org/10.1590/010264452015009400008

BOURDIEU, Pierre. A economia das trocas simbólicas. São Paulo: Perspectiva, 1974.

BOURDIEU, Pierre. La distinction. Critique sociale du jugement. Paris: Éditions de Minuit, 1979.

BOURDIEU, Pierre. Introduction à la socioanalyse. Actes de la Recherche en Sciences Sociales, n. 90, p. 3-5, 1991.

BOURDIEU, Pierre. Les règles de l'art. Genèse et structure du champ littéraire. Paris: Seuil, 1992.

BOURDIEU, Pierre. Esquisse pour une auto-analyse. Paris: Raisons d'agir, 2004.

BOURDIEU, Pierre. Manet. Une révolution symbolique. Paris: Seuil, 2013.

BOURDIEU, Pierre et al. Un art moyen. Essai sur les usages sociaux de la photographie. Paris: Éditions de Minuit, 1965.

BOURDIEU, Pierre; DARBEL, Alain. L'amour de l'art: les musées et leur public. Paris: Éditions de Minuit, 1966.

BOURDIEU, Pierre; DARBEL, Alain. O amor pela arte. Os museus de arte na Europa e seu público. São Paulo: EDUSP/ZOUK, 2003.

BOURDIEU, Pierre; DELSAUT, Yvette. Le couturier et sa griffe. Contribution à une théorie de la magie. Actes de la Recherche en Sciences Sociales, n. 1, p. 7-36, 1975. 
BOURDIEU, Pierre; PASSERON, Jean-Claude. Les héritiers. Les étudiants et la culture. Paris: Éditions de Minuit, 1964.

BOURDIEU, Pierre; PASSERON, Jean-Claude. La reproduction. Eléments pour une théorie du système d'enseignement. Paris: Éditions de Minuit, 1970.

BRAGA, Maria Lúcia de Santana. A recepção do pensamento de Roger Bastide no Brasil. Sociedade e Estado, v. 15, n. 2, 2000. http://dx.doi.org/10.1590/S0102-69922000000200007

BUENO, Maria Lucia. Sociologia das Artes Visuais no Brasil. São Paulo: Editora do Senac, 2012.

BUENO, Maria Lucia; SANT'ANNA, Sabrina Parracho; DABUL, Lígia. Sociologia da arte: notas sobre a construção de uma disciplina. Revista Brasileira de Sociologia, v. 6, n. 12, p. 266-289, 2018. http://dx.doi.org/10.20336/rbs.233

CANDIDO, Antonio. Prefácio. In: MICELI, Sergio. Intelectuais à brasileira. São Paulo: Companhia das Letras, 2001.

CATANI, Afranio Mendes. A sociologia de Pierre Bourdieu (ou como um autor se torna indispensável ao nosso regime de leituras). Educaçáo e Sociedade, v. 23, n. 78, p. 57-75, 2002. http://dx.doi.org/10.1590/S010173302002000200005

CRANE, Diana. The Transformation of Avant-Garde. Chicago: University of Chicago Press, 1987.

CUCHE, Denys. Roger Bastide, le "fait individuel" et l'école de Chicago. Cahiers Internationaux de Sociologie, v. 1, n. 124, p. 41-59, 2008. Disponível em: <https://www.cairn.info/revue-cahiers-internationaux-de-sociologie2008-1-page-41.htm>. Acesso em: 10 mar. 2019.

DESROSIERES, Alain; THEVENOT, Laurent. Les catégories socio-professionnelles. Paris: La Découverte, 1988.

DURAND, José Carlos. Arte, privilégio e distinçáo. Artes plásticas, arquitetura e classes dirigentes no Brasil, 18551985. São Paulo: Perspectiva, 1989.

GUYAU, Jean-Marie. L’art au point de vue sociologique. Paris: Alcan, 1889.

HENNION, Antoine. La passion musicale. Une sociologie de la médiation. Paris: Éditions Métailé, 2007.

JACKSON, Luis Carlos. Geraçôes Pioneiras na Sociologia Paulista. Tempo Social, v. 19, n. 1, p. 115-130, 2007. http://dx.doi.org/10.1590/S0103-20702007000100007

KING, Anthony. Thinking with Bourdieu against Bourdieu: a pratical critique of habitus. Sociological Theory, v. 18, n. 3, p. 417-433, 2000. https://doi.org/10.1111\%2F0735-2751.00109

LALO, Charles. L'art et la vie sociale. Paris: Doin, 1927.

MICELI, Sergio. Imagens negociadas. São Paulo: Companhia das Letras, 1996.

MICELI, Sergio. Nacional estrangeiro: história social e cultural do modernismo artístico em São Paulo. São Paulo: Companhia das Letras, 2003.

MICELI, Sergio. Intelectuais à brasileira. São Paulo: Companhia das Letras, 2005.

MICELI, Sergio (org.). História das Ciências Sociais no Brasil. São Paulo: Vértice/IDESP, 1989. v. 1.

MOULIN, Raymonde. Le marché de la peinture en France. Paris: Éditions de Minuit, 1967.

MOULIN, Raymonde. Les bourgeois amis des arts: les expositions des Beaux-arts en province, 1885-1887. Revue Française de Sociologie, v. 17, n. 3, p. 383-422, 1976. https://doi.org/10.2307/3321021

MOULIN, Raymonde. L'artiste, l'institution et le marché. Paris: Flammarion, 1992. 
MOULIN, Raymonde (org). Sociologie de l’art. Paris: La Documentation Française, 1986.

ORTIZ, Renato. A moderna tradição brasileira. São Paulo: Brasiliense, 1988.

ORTIZ, Renato. Nota sobre a recepção de Pierre Bourdieu no Brasil. Sociologia \& Antropologia, v. 3, n. 5, p. 81-90, 2013. http://dx.doi.org/10.1590/2238-38752013v353

PEIXOTO, Fernanda. Diálogos brasileiros: uma análise da obra de Roger Bastide. São Paulo: Edusp/Fapesp, 2000.

PÉQUIGNOT, Bruno. Sociologie des arts. Paris: Armand Colin, 2009.

PINHEIRO FILHO, Fernando Antonio. Roger Bastide e a moderna sociologia da arte. TempoSocial, v. 18, n. 2, p. 291-293, 2006. Disponível em: <http://www.scielo.br/scielo.php?script=sci_arttext\&pid=S0103-20702006000200015\&lng=e n\&nrm=iso >. Acesso em: 17 maio 2019. http://dx.doi.org/10.1590/S0103-20702006000200015

PULICI, Carolina. De como o sociólogo deve praticar o seu ofício: as cátedras de Sociologia da USP entre 1954 e 1969. Dissertação (Mestrado) - Faculdade de Filosofia, Letras e Ciências Humanas da Universidade de São Paulo, São Paulo, 2004.

QUEMIN, Alain. Trente ans d'enquête sur les publics du Centre Pompidou. In: DUFRENE, Bernadette (org.). Centre Pompidou: 30 ans d'histoire. Paris: Éditions du Centre Georges Pompidou, 2007. p. 494-498.

QUEMIN, Alain. Les Stars de L'Art Contemporain. Notoriété et consécration artistiques dans les Arts Visuels. Paris: CNRS Éditions, 2013.

QUEMIN, Alain. The sociology of Art. In: KORGEN, Kathleen (org.). Cambridge Handbook of Sociology. Cambridge: Cambridge University Press, 2017. p. 293-303.

QUEMIN, Alain; LÉVY, Clara. La fortune critique de Pierre Francastel en sociologie de l'art en France: un héritage limité. In: DUFRENE, Thierry (org.). Pierre Francastel. L'hypothèse même de l'art. Paris: Éditions de l'Institut National d'Histoire de l'Art, 2010. p. 51-61.

QUEMIN, Alain; VILLAS-BÔAS, Glaucia. Introdução. In: QUEMIN, Alain; VILLAS-BÔAS, Glaucia (orgs.). Arte e Vida Social. Pesquisas recentes no Brasil e na França. Marselha: Open Edition, 2016. v. 1.

SAPIRO, Gisèle; BUSTAMANTE, Mauricio. Translation as a measure of international consecration: mapping the world distribution of Bourdieu's Books in translation. Sociologica, v. 2-3, p. 1-45, 2009. http://dx.doi. org/10.2383/31374

SIMIONI, Ana Paula Cavalcanti. Bordado e transgressão: questôes de gênero na arte de Rosana Paulino e Rosana Palazyan. Proa, Campinas, v. 1, n. 2, p. 1-19, 2010.

SIMIONI, Ana Paula Cavalcanti. Profissáo artista: pintoras e escultoras acadêmicas brasileiras, 1880-1922. São Paulo: EDUSP/FAPESP, 2008.

TEIXEIRA, João Gabriel. Dossiê: Sociologia da Arte Hoje. Sociedade \& Estado, v. 20, n. 2, p. 297-424, 2005.

VILLAS BÔAS, Glaucia K.; OELZE, Berthold. Georg Simmel. Arte e vida. Ensaios sobre estética sociológica. São Paulo: Hucitec, 2016. v. 1.221 p.

WAIZBORT, Leopoldo. As aventuras de Georg Simmel. São Paulo: Editora 34, 2000. v. 1. 592 p.

WEBER, Max. Sociologie de la musique. Les fondements rationnels et sociaux de la musique. Paris: Anne-Marie Métailié, 1998.

ZOLBERG, Vera. Constructing a Sociology of the Arts. Nova York: Cambridge University Press, 1990. 


\section{Resumo}

\section{A contribuiçāo de Pierre Bourdieu para a sociologia da arte (França e Brasil)}

O artigo analisa a contribuição da sociologia da arte de Pierre Bourdieu para a França e para o Brasil. Pretendemos discutir a importância de sua obra especialmente no que diz respeito ao processo de institucionalização e reconhecimento da sociologia da arte enquanto disciplina. Enquanto na França, sobretudo a partir dos anos 1990, se verificaram alargamento no conjunto de autores e diversificação metodológica, cada vez mais a reputação de Pierre Bourdieu enquanto o grande sociólogo da arte francês crescia no exterior. Nesse sentido, para mensurar o renome conquistado pelo autor, é preciso compreender o peso que a recepção de sua obra teve fora da França. O Brasil foi um dos países a contribuir para essa centralidade que em seu país de origem não era assim tão certa, pois sofria com a concorrência de outros intelectuais, como Raymonde Moulin, cuja importância também é evidenciada neste texto.

Palavras-chave: Pierre Bourdieu; Sociologia da arte; Recepção; Institucionalização; Raymonde Moulin.

\section{Abstract}

\section{La contribution de Pierre Bourdieu a la sociologie de l'art (France et Bresil)}

L'article analyse l'influence de la sociologie de l'art de Pierre Bourdieu en France et au Brésil. Les auteurs discutent l'importance de son travail, en particulier en ce qui concerne le processus d'institutionnalisation et la reconnaissance de la sociologie de l'art en tant que discipline spécifique. Alors qu'en France, surtout depuis les années 1990, le nombre d'auteurs spécialisés dans le domaine a augmenté et tandis que la diversité d'approches s'est accrue, la réputation de Pierre Bourdieu en tant que grand sociologue de l'art français de référence s'est de plus en plus imposée à l'étranger. Le renom acquis par l'auteur est à mettre en relation avec le poids de la réception de son travail en dehors de la France. Le Brésil a été l'un des pays qui a contribué à ce processus de centralité qui, dans le pays d'origine de Pierre Bourdieu, n'est pas aussi claire au sein du domaine, en raison de la concurrence, certes intellectuelle mais également institutionnelle, d'autres collègues, dont Raymonde Moulin, dont l'importance est également mise en évidence dans ce texte.

Mots-clés: Pierre Bourdieu; Sociologie de l'art; Réception; Institutionalisation; Raymonde Moulin.

\section{Résumé}

\section{Pierre Bourdieu's contribution to the sociology of art (France and Brazil)}

This article analyzes the contribution of the sociology of art of Pierre Bourdieu both in France and in Brazil. We discuss the importance of his work especially as regards the process of institutionalization and recognition of sociology of art as a discipline. While in France, especially since the 1990s, there has been an increase in the number of authors and a diversification of approaches, the reputation of Pierre Bourdieu as «the» great French sociologist of art grew abroad. In this sense, to measure the name conquered by the author, it is necessary to understand the weight that the reception of his work had outside of France. Brazil was one of the regions to contribute to this centrality which, in Pierre Bourdieu's country of origin, was not so established, because it suffered from competition with other sociologists of art such as Raymonde Moulin, whose own importance is also underlined in this text.

Keywords: Pierre Bourdieu; Sociology of arts; Reception; Institutionalization; Raymonde Moulin.

(c) 2019 Associação Nacional de Pós-Graduação e Pesquisa em Ciências Sociais - ANPOCS Este é um artigo de acesso aberto distribuído nos termos de licença Creative Commons. 